\title{
Modeling demand/supply of water resources in the arid region of northwestern China during the late 1980s to 2010
}

\author{
LIU Xingran ${ }^{1,2}$, ${ }^{*}$ SHEN Yanjun ${ }^{1}$, GUO Ying ${ }^{1}$, LI Shuo ${ }^{1}$, GUO Bin ${ }^{3}$
}

1. Key Laboratory of Agricultural Water Resources, Center for Agricultural Resources Research, Institute of Genetics and Developmental Biology, CAS, Shijiazhuang 050021, China;

2. University of Chinese Academy of Sciences, Beijing 100049, China;

3. College of Geomatics, Shandong University of Science and Technology, Qingdao 266510, Shandong, China

\begin{abstract}
Water demand increases continuously with an increasing population and economic development. As a result, the difference between water supply and demand becomes a significant issue, especially in arid regions. To figure out the utilization of water resources in the arid region of northwestern China (ARNWC), and also to provide methodologies to predict the water use in future, three models were established in this study to calculate agricultural irrigation, industrial and domestic water use in the ARNWC from the late 1980s to 2010. Based on river discharges in the region, the supply and demand of water resources at the river basin level were analyzed. The results indicated that agricultural irrigation demand occupies more than $90 \%$ of the total water use in the ARNWC. Total water demand increased from $31.97 \mathrm{~km}^{3}$ in the late $1980 \mathrm{~s}$ to $48.19 \mathrm{~km}^{3}$ in 2010 . Most river basins in this arid region were under medium and high water stress. Severe-risk river basins, such as the Shiyang river basin and the eastern part of the northern piedmont of the Tianshan Mountains, were found in this region. It was revealed that the water supply became critical from April to May, which was the season of the lowest water supply as determined by comparing monthly water consumption.
\end{abstract}

Keywords: agricultural irrigation water demand; industrial water demand; domestic water demand; total water demand; supply and demand of water resources; arid region of northwestern China

\section{Introduction}

Water is indispensable to all creatures and human beings. It is an irreplaceable precious natural resource for agricultural and industrial production, economic development and environmental improvement. With the rapid growth of the world population and economic development, global water consumption is growing quickly, and water supply is facing with many challenges, especially the problem of water scarcity (Shen et al., 2014). The world

Received: 2014-10-27 Accepted: 2015-01-15

Foundation: National Key Project on Basic Research (973), No.2010CB951003; The National Science and Technology Project, No.2014BAD10B06

Author: Liu Xingran (1988-), Master Candidate, specialized in ecological hydrology. E-mail: liuxingran2007@126.com

*Corresponding author: Shen Yanjun, PhD and Professor, E-mail: yjshen@sjziam.ac.cn 
population increased from 1.6 billion in 1900 to 7.1 billion in 2012 (RMN, 2012). Global agricultural water consumption increased 7-fold during the past century, and industrial and domestic water consumption increased 20 and 10 times, respectively (Guo, 2013). Currently, approximately $70 \%$ of the freshwater worldwide is used for irrigation and $20 \%$ for industry, while domestic water use accounts for approximately 10\% (Shen et al., 2008).

China has relatively abundant water resources that ranked sixth in the world in terms of absolute amount of annual runoff. However, with its large population of approximately 1.3 billion, the quantity of water resources per capita is very low (approximately one-quarter of the world average), and therefore, China is a country that experiences some of the most severe water shortages in the world (Xia and Chen, 2001; Liu and Diamond, 2005). In addition, China also has underlying water shortages, which refers to the considerable spatial-temporal variability of the distribution of water resources from south to north and from inland to coast (Xia and Chen, 2001; Piao et al., 2010; Dai et al., 2013; Nian et al., 2014). However, the total water demand in China has been growing remarkably, increasing from $443.7 \mathrm{~km}^{3} \mathrm{yr}^{-1}$ in 1982 to $554.1 \mathrm{~km}^{3} \mathrm{yr}^{-1}$ in 2011(WB, 2013). This forms a sharp contradiction between the increasing water demand and the limited water resources.

The arid region of northwestern China (ARNWC) is one of the areas hit by the most severe water shortages. The annual precipitation is less than $200 \mathrm{~mm}$ in most places, but potential evapotranspiration can be as much as 3000 mm (Shen et al., 2010; 2013). The water scarcity and highly uneven spatial-temporal distribution of rainfall, which gradually decreases from east to west, lead to vulnerable ecosystems (Li et al., 2013). Meanwhile, the unplanned exploitation of water resources results in land desertification, soil salinization and water pollution (Feng et al., 2000). With the increasing population and growing economy, the total used surface and groundwater in ARNWC can increase considerably from 30.87 billion $\mathrm{m}^{3} \mathrm{yr}^{-1}$ at surface development stage to 50.97 billion $\mathrm{m}^{3} \mathrm{yr}^{-1}$ at a comprehensive development of surface and groundwater stage (Feng et al., 2000). In addition, the total water shortage in this region is projected to be $\sim 15 \mathrm{~km}^{3}$ by the early 21st century (CASGA, 1996). Water has become the key factor restricting socio-economic development and ecological security (Bao et al., 2006). Therefore, it is urgent to project the spatial and temporal distributions of water demand and supply and help improve the water governance in this region.

Many studies have been conducted to analyze the supply and demand of water resources. The demand of water resources in some studies was directly based on statistical data (Feng et al., 2006; Tang et al., 2002). Some studies were based on estimated data using proper methodology. For example, Alcamo et al. (2003) developed and tested a model called WaterGAP 2 to estimate global water use and availability. Qi et al. (2010) established the System Dynamics model on the usage of water resources to simulate the quantity of agricultural, industrial, domestic, livestock and ecological water demands in Yanqi County, Xinjiang, China. Li et al. (2012) used the evaporation coefficients and quotas to estimate comprehensive average water demand from 2000 to 2009 in the oasis of the Kaidu-Kongque River Basin. Ji et al. (2006) established a model of supply and demand of water resources combined with meteorology, hydrology, soil, vegetation, plantation structure and economic development in the midstream of the Heihe River to calculate and evaluate the supply and demand of water resources. Shen and Chen (2010) provided a global perspective on the hydrology and water balance of six major arid basins in the world. However, little is known about 
long-term trends and the spatial distribution of total water demand in any part of the world (Jon and Chang, 2009) and the pressure on water resources from total water demand, especially in the ARNWC.

The main purpose of this study is to estimate the spatio-temporal distribution of total water demand from agriculture, industry and domesticity in the ARNWC and to analyze the supply and demand of the total water resources in this region. This study can also lay a strong foundation for the prediction of future water use in the ARNWC. This paper is based on our earlier works on water requirements for irrigation (Shen et al., 2013) and domestic water use (Guo et al., 2012). Because the spatio-temporal distribution of industrial water use in ARNWC has rarely been calculated, we will present a simple model for industrial water use by considering the statistical relationship between industrial water use intensity and regional economic level, i.e. GDP per capita. The socio-economic water demand, namely, water used in agricultural, industrial, and domestic sectors, in the ARNWC will be firstly estimated by considering the spatial variation and temporal development during the late 1980s to the present. The water demand/supply situation and water stress also will be analyzed. We believe the results of this study will help to improve the water management in this special region with highly water shortage. All datasets about the water demand in different sectors presented in this paper will be made available for free on the following Internet address: http://hydro.sjziam.ac.cn/dataload.aspx. We hope that these data will be a useful source for other researchers and water resource managers who are interesting with the water resources issues in this arid region.

\section{Study area and data}

The ARNWC is located in the middle latitude of the Eurasian hinterland, mainly including the Xinjiang Uygur Autonomous Region, the Hexi Corridor in Gansu Province, and the western portion of the Helan Mountains in Inner Mongolia (Figure 1). It lies between longitude $73.48^{\circ}-106.96^{\circ} \mathrm{E}$ and latitude $34.84^{\circ}-49.18^{\circ} \mathrm{N}$ (Guo et al., 2013) with an area of approximately 2.02 million $\mathrm{km}^{2}$ (Shen et al., 2013). This region is bordered on the south by the Kunlun-Altun-Qilian Mountains, which block water vapor from the Indian Ocean along with the Qinghai-Tibet Plateau, and on the north by the Altai Mountains, which obstruct water vapor from the Arctic Ocean. Meanwhile, the Helan Mountains serve as the eastern border, blocking water vapor from the easterly monsoon. There are the Tianshan Mountains, intercepting westerly water vapor and acting as a wet island in the arid region, lying in the middle of the region cutting from east to west the Xinjiang Uygur Autonomous Region into two parts. In this study, the part to the north of the Tianshan Mountains is called Northern Xinjiang (NX), and the part located to the south of the Tianshan Mountains is called the Tarim River Basin (TRB). The area to the north of the Qilian Mountains and the west of Helan Mountains is called the Qilian-Hexi Region (QH). There is a barren desert region without human beings located in the central part, we called it Central Barren Region (CB).

The study area possesses a typical inner-continental climate with sufficient sunshine, great temperature variations, scarce precipitation and low humidity (Li et al., 2013; Wang et al., 2013). The area where annual precipitation is less than $50 \mathrm{~mm} \mathrm{yr}^{-1}$ occupies more than one-third of the ARNWC (Wang et al., 2013). Although the inland rivers in China are mostly 
concentrated here, some rivers with small discharges disappear in the Gobi and other deserts because of intense evaporation and infiltration. Additionally, some large rivers such as the Tarim, Heihe and Shiyang Rivers flow to depressions and become inland lakes (Feng et al., 2000; Chen et al., 2011). As mountain precipitation and glacier melt water are the main water source in the piedmont zone, the mountainous runoff of the inland river basin can be taken as almost the total available water resources of the inland basin.

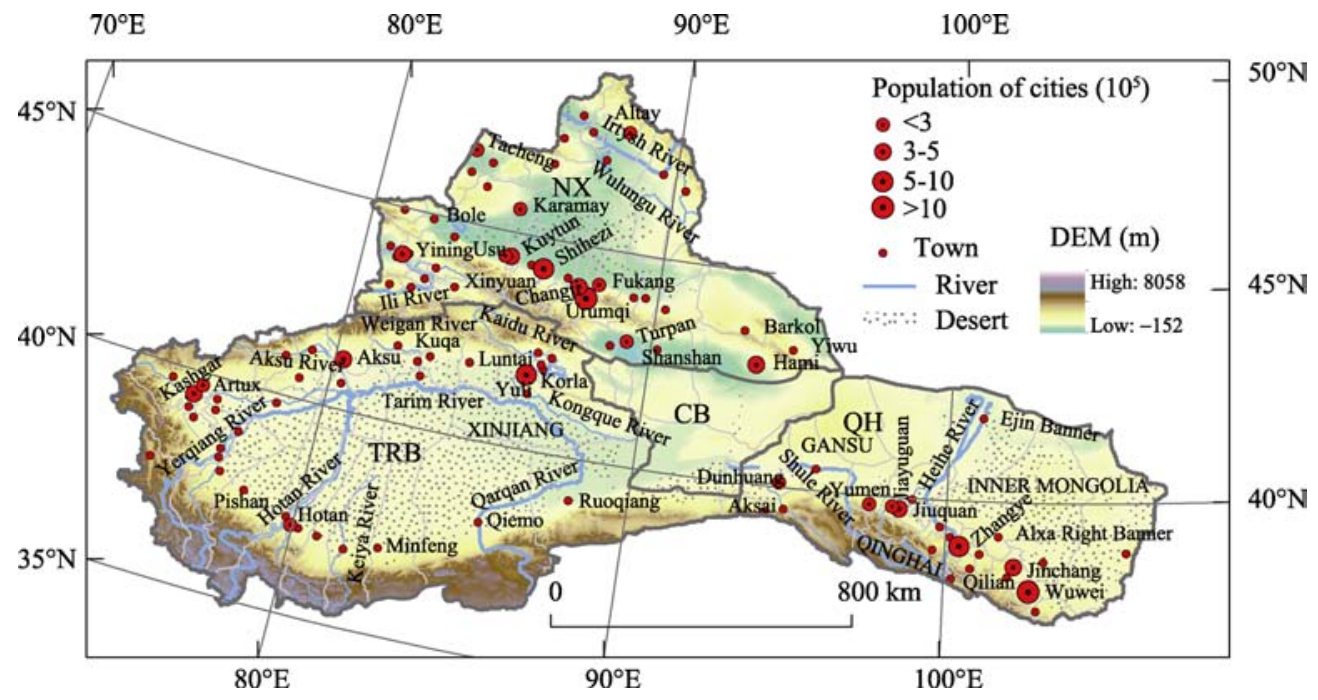

Figure 1 DEM, cities, towns, major rivers and desert areas in the arid region of northwestern China

There are abundant resources in the study area including farmlands, minerals and solar-thermal energy. However, the scarce precipitation limits the development of agriculture. Furthermore, the rapid growth of urbanization in the arid region leads to the increased use of water, reducing the supply of water for agriculture. Thus, agricultural and rural areas draw water from natural ecosystems to lessen the economic loss (Bao and Fang, 2007). Moreover, with the increasing population and unplanned exploitation of land and water resources, the contradiction between ecological degradation and economic development has become more apparent and complicated. Consequently, water has become the main restrictive factor for socio-economic development and ecological conservation.

\subsection{Data for agricultural irrigation water demand}

Data on meteorology, social economy and land use were used to calculate the water demand of agricultural irrigation. Daily meteorological observations (67 meteorological stations) were collected from the Chinese Meteorological Administration (CMA), including the maximum, minimum and average temperatures, wind speed, relative humidity and sunshine duration. Data on crop growth and phenology were collected from various agricultural meteorological stations. Socio-economic data came from the statistical yearbooks of the provinces, municipalities and prefectures (1989-2010) in the study area, including cultivated land area at the county level and the sown areas of various crops. Land use data in 1990 and 2000 at $1 \mathrm{~km} \times 1 \mathrm{~km}$ resolution were provided by the Data Center of Resources and Environment, Chinese Academy of Sciences. Combined with the socio-economic data and statistics, land use data were used to create the spatial distributions of the area of sown crops in 
different years.

\subsection{Data for the spatial distributions of population and GDP}

County-level socio-economic data were used to create spatial distributions of population and GDP. Socio-economic data about the agricultural and non-agricultural population, primary, secondary, and tertiary industry GDP and per capita GDP were obtained from the Xinjiang Statistical Yearbook, Gansu Yearbook, Qinghai Statistical Yearbook and Inner Mongolia Statistical Yearbook (1985-2010). Urban and rural populations were assigned to each grid according to the proportional distribution of urban and rural land use. GDP of secondary and tertiary industries was distributed to each grid cell in proportion to the urban population. Similarly, primary industry GDP was distributed to each grid cell in proportion to the rural population.

\subsection{Data for industrial water demand}

The statistical data that included industrial water use, GDP per capita, water consumption per unit of industrial added value and secondary industrial GDP for main cities were used to build the industrial water use model. The data were from the Xinjiang Statistical Yearbook (1985-2010), Gansu Water Resources Bulletin (2000-2010), Gansu Yearbook (1985-2010), Qinghai Statistical Yearbook (1985-2010) and Inner Mongolia Statistical Yearbook (1985-2010).

\subsection{Data for domestic water demand}

In the current study, government statistical data and field investigation data were used to build the domestic water use model. The government statistical data included socio-economic data (tertiary industrial GDP and per capita GDP) and water quantity data (per capita domestic water use and total domestic water use). County-level socio-economic data were acquired from the Xinjiang Statistical Yearbook, Gansu Yearbook, Qinghai Statistical Yearbook and Inner Mongolia Statistical Yearbook (1985-2010). Urban per capita domestic water use data were collected from the China City Statistical Yearbook (1985-2010) and the China Urban Construction Statistical Yearbook (2000-2009). Rural per capita domestic water use data were originally obtained from investigations in rural households. To evaluate the presented models, total domestic water use data at prefecture level for the years 2004 and 2009 were obtained from the Xinjiang Water Resources Bulletin and Gansu Water Resources Bulletin.

\subsection{Data for water supply}

Monthly river discharge data from hydrometric stations from 1989-2010 were selected for analyzing the water supply and demand of each basin.

\section{Methodology}

In this study, three models were established for estimating agricultural, industrial, and domestic water use. Through allocating the water demand to grid cells, we obtained the distri- 
bution maps of each water demand. By combining maps of crop irrigation demand, industrial water demand and domestic water demand, the total water demand in the ARNWC was obtained.

\subsection{Estimation of crop irrigation demand}

Assuming that the crops in the study area can get full irrigation, the crop irrigation requirement model was created as follows (Shen et al., 2013):

$$
\begin{gathered}
C W R=E T_{\mathrm{c}}-P_{e} \\
E T_{c}=K_{c} \times E T_{0} \\
I W R=S \times C W R / I_{c}
\end{gathered}
$$

where $C W R$ is the water requirement of a certain crop; $K_{c}$ is the crop coefficient; $E T_{0}$ is the reference evapotranspiration which is calculated by the Penman-Monteith equation recommended by the United Nations Food and Agriculture Organization (FAO); $S$ is the sown area of a certain crop; $P_{e}$ is the efficient precipitation; $I_{c}$ is the irrigation efficiency; and $I W R$ is the irrigation water requirement of the crop. $E T_{0}$ is calculated by the Penman-Monteith equation:

$$
E T_{0}=\frac{0.408 \Delta\left(R_{n}-G\right)+\gamma \frac{900}{T+273} u_{2}\left(e_{s}-e_{a}\right)}{\Delta+\gamma\left(1+0.34 u_{2}\right)}
$$

where $E T_{0}$ is the reference evapotranspiration $(\mathrm{mm} / \mathrm{d}) ; R_{n}$ is net radiation at crop surface $\left[\mathrm{MJ} /\left(\mathrm{m}^{2} \cdot \mathrm{d}\right)\right] ; G$ is the soil heat flux density $\left[\mathrm{MJ} /\left(\mathrm{m}^{2} \cdot \mathrm{d}\right)\right] ; u_{2}$ is the wind speed at a height of 2 $\mathrm{m}(\mathrm{m} / \mathrm{s}) ; T$ is the temperature at a height of $2 \mathrm{~m}\left({ }^{\circ} \mathrm{C}\right) ; e_{s}$ is the saturation vapor pressure $(\mathrm{kPa})$; $e_{a}$ is the actual vapor pressure $(\mathrm{kPa}) ; \Delta$ is the slope of the vapor pressure curve $\left[\mathrm{kPa} /{ }^{\circ} \mathrm{C}\right]$; and $\gamma$ is the psychrometric constant $\left[\mathrm{kPa} /{ }^{\circ} \mathrm{C}\right]$ (Er-Raki et al., 2007).

$$
P_{\mathrm{e}}=P \times \delta
$$

where $P$ is the precipitation and $\delta$ is an empirically effective utilization coefficient of rainfall, which is adopted as 0.52 in the current study (Xu et al., 2010). $K_{c}$ during the growing period is based on Duan et al. (2004). $I_{C}$ has increased from 0.38 to 0.48 in the ARNWC according to the China Water Conservancy Yearbook and the regional water resources bulletins during the past 20 years (Table 1).

To generate the spatial distribution of $E T_{c}$, the Thiessen polygon method was used for spatial interpolation based on 67 meteorological observation stations. In addition, the distribution of the crop growing area was rasterized using the statistics and land use maps. Refer to Shen et al. (2013) for further details.

Table 1 Development of irrigation efficiency in the arid region of northwestern China during the past 20 years

\begin{tabular}{cccccc}
\hline Year & 1990 & 1995 & 2000 & 2005 & 2010 \\
\hline$I_{c}$ & 0.38 & 0.40 & 0.42 & 0.45 & 0.48 \\
\hline
\end{tabular}

\subsection{Estimation of industrial water demand}

According to the explanatory notes on main statistical indicators of the statistical yearbook, industrial water use refers to the water consumption used in industrial and mining enter- 
prises in the process of production for manufacturing, processing, cooling, air conditioning, washing, and heating a boiler, etc., calculated by the new water dosage minus the reused water within the enterprise. Generally the amount of industrial water use is mainly determined by the progress of technology and level of economic development. Areas with a high level of economic development have a higher percentage of industrial water use than relatively undeveloped economic areas. Meanwhile, the improvement in the recycling rate of industrial water can decrease the industrial water demand, which is more obvious in developed countries (Oki and Kanae, 2006). The empirical data from developed countries shows that industrial water use undergoes two main phases with economic development: a growth phase, in which industrial water use increases, and a saturation phase, in which industrial water can either remain constant or decrease (Jia et al., 2006). The industrial water use in the ARNWC is undergoing a growth phase. In this study, we used per capita GDP as the driving factor to represent the level of economic development.

Industrial water use can be calculated through water use per unit of industrial added value and secondary industry GDP, using the following formula:

$$
Y_{I}=y_{i} \times I G D P
$$

where $Y_{I}$ is the industrial water use $\left(\mathrm{m}^{3}\right)$; $y_{i}$ is the water use per unit industrial added value ( $\mathrm{m}^{3} / 10^{4}$ yuan); and IGDP is the secondary industry GDP $\left(10^{4}\right.$ yuan $)$.

To determine $y_{i}$, a model was employed that considered the relationship between $y_{i}$ and GDP per capita. According to the published data on water use per unit of industrial added value and GDP per capita at the prefecture level in the Gansu Water Resources Bulletin (2000-2010) and Xinjiang Statistical Yearbook (2000-2010), a scatter plot was drawn to fit an equation, as shown in Figure 2. The relationship between water use per unit of industrial

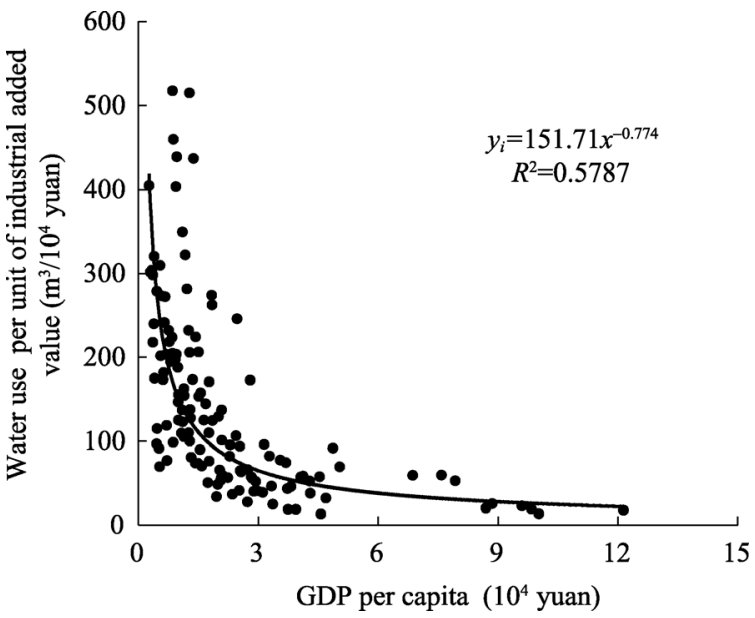

Figure 2 The relationship between water use per unit of industrial added value and GDP per capita from 2000 to 2010 in the arid region of northwestern China added value and GDP per capita was defined as below:

$$
y_{i}=151.71 x^{-0.774}
$$

where $y_{i}$ is water use per unit of industrial added value $\left(\mathrm{m}^{3} / 10^{4}\right.$ yuan) and $x$ is GDP per capita ( $10^{4}$ yuan).

To evaluate the methodology of the industrial water use model, statistical industrial water use data at the prefecture level in the Xinjiang Uygur Autonomous Region for the years 2005 and 2009 were compared to the modeled data. To evaluate the performance of the presented model, the root mean square error (RMSE), which reflects the deviation between the estimated and actual value, and model efficiency (ME), which indicates the goodness of fit with regard to a 1:1 line (ME=1 means perfect fitness), were calculated as follows (Vassolo and Döll, 2005): 


$$
\begin{gathered}
R M S E=\sqrt{\frac{\sum_{i=1}^{n}\left(Y_{\text {stat }, i}-Y_{\text {mod }, i}\right)^{2}}{n}} \\
M E=1-\frac{\sum_{\mathrm{i}=1}^{n}\left(Y_{\text {mod }, i}-Y_{\text {stat }, i}\right)^{2}}{\sum_{i=1}^{n}\left(Y_{\text {stat }, i}-\overline{Y_{\text {stat }}}\right)^{2}}
\end{gathered}
$$

where $Y_{\text {stat }, i}$ is the statistical industrial water use of a certain administrative region; $Y_{\text {mod, } i}$ is the modeled industrial water use of a certain administrative region; $\overline{Y_{\text {stat }}}$ is the mean value of total statistical industrial water use; and $n$ is the number of administrative regions.

The RMSE of the model is approximately $0.02 \mathrm{~km}^{3}$, and the $\mathrm{ME}=0.85$. In addition, a scatter plot between the modeled and statistical industrial water use is uniformly distributed along the 1:1 line (Figure 3), which means that industrial water use model can simulate the

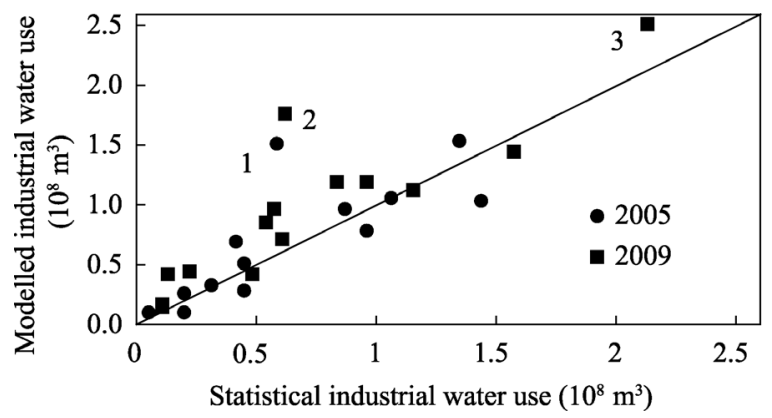

Figure 3 Comparison of modeled and statistical total industrial water use at the prefecture level for 2005 and 2009 in the arid region of northwestern China actual industrial water use well. The results show that the modeled industrial water use in most prefectures agrees well with the statistical industrial water use for the years 2005 and 2009. The prefecture with the highest industrial water use is Urumqi (point 3 in Figure 3) for both years. According to our estimation, the industrial water use in Urumqi in 2009 has reached $0.251 \mathrm{~km}^{3}$, which compares well with the statistical value $\left(0.214 \mathrm{~km}^{3}\right)$.

Despite the good agreement, there are still some points that deviate from the 1:1 line, such as points 1 and 2, which represent Bayingolin Mongolian Autonomous Prefecture (Bazhou). This may be because the corps were not distinguished from the local demand and we dealt with them as a total when estimating the water consumption per unit of industrial added value in Bazhou. Therefore, the estimated industrial water use is higher than the statistical value there.

The secondary industry in China is mainly distributed in urban areas. To obtain the spatial distribution of industrial water use, we allocated the industrial water use to grid cells according to the distribution of urban population. We assumed that the spatial distribution of industrial water use was proportional to the urban population distribution within a given administrative region. The geographical distribution of urban populations was generated based on county-level statistical data and land-cover data as mentioned above. Statistical county-based urban population data were distributed to each grid cell in proportion to urban land use at a spatial resolution of $1 \mathrm{~km} \times 1 \mathrm{~km}$.

\subsection{Estimation of domestic water demand}

Domestic water use includes urban and rural domestic water use. Due to a large difference between urban and rural areas in this region, they were estimated separately. With the me- 
method presented in Guo et al. (2012), urban domestic water use per capita can be estimated with the following model:

$$
y_{u}=a \cdot \ln x-b
$$

where $y_{u}$ is domestic water use per capita (L/cap d) in urban areas; $x$ is GDP per capita (yuan) in urban areas; and $a$ and $b$ are coefficients.

Urban domestic water use varies based on city size: the larger the city size, the greater is the domestic water use. Cities in the study area were divided into three groups according to their population, GDP per capita and domestic water use per capita in 2009 using the K-means clustering algorithm. The results showed that cities with per capita GDP $<5 \times 10^{4}$ yuan belong to the first cluster, which could be modeled as follows:

$$
y_{u}=32.64 \ln x-136.25
$$

those with per capita GDP between $5 \times 10^{4}$ and $10 \times 10^{4}$ belong to the second cluster, which could be estimated as follows:

$$
y_{u}=34.33 \ln x-143.94
$$

and the rest of the cities with per capita GDP $>10 \times 10^{4}$ yuan belong to the third cluster, which could be calculated by:

$$
\mathrm{y}_{u}=40.56 \ln x-230.75
$$

Because little information is available on rural domestic water use, based on the field investigation data and the Water Resources Bulletin of China, rural domestic water use was assumed to be one-quarter of its geographically nearest urban value. The model for rural per capita domestic water use is expressed as follows:

$$
\mathrm{y}_{r}=1 / 4 y_{u}
$$

where $y_{r}$ is per capita domestic water use (L/cap d) in rural areas.

The urban and rural total annual domestic water use in each grid cell was respectively calculated by:

$$
\begin{gathered}
Y_{u}=365 y_{u} p_{u} / 1000 \\
Y_{r}=365 y_{r} p_{r} / 1000 \\
Y=Y_{u}+Y_{r}
\end{gathered}
$$

where $Y_{u}$ is the annual urban domestic water use $\left(\mathrm{m}^{3} / \mathrm{yr}\right) ; p_{u}$ is the urban population; $Y_{r}$ is the annual rural domestic water use $\left(\mathrm{m}^{3} / \mathrm{yr}\right) ; p_{r}$ is the rural population; and $Y$ is the total annual domestic water use $\left(\mathrm{m}^{3} / \mathrm{yr}\right)$.

\section{Results and discussion}

\subsection{The spatial-temporal features of agricultural irrigation demand}

With the adjustment of plantation structure and increase in the area sown with crops in the study area, agricultural irrigation demand has increased from $31.14 \mathrm{~km}^{3}$ in 1989 to 37.15 $\mathrm{km}^{3}$ in 2000 and $44.98 \mathrm{~km}^{3}$ in 2010, an annual increase of $\sim 0.66 \mathrm{~km}^{3}$. For the sub-regions during 1989 to 2010, the irrigation requirement in NX and TRB increased by 6.40 and 7.63 $\mathrm{km}^{3}$, respectively. However, the irrigation requirement in $\mathrm{QH}$ decreased by $0.18 \mathrm{~km}^{3}$. Areas with large irrigation demand were mainly distributed in the northern piedmont of the Tianshan Mountains and in the TRB river basins of Yerqiang, Kashgar, Aksu, Ili, Ebi Lake, Wei- 
gan and Kaikong (Figure 4). The irrigation demand in $\mathrm{QH}$ was low and mostly distributed along the Hexi Corridor. In the first 10 years from 1989 to 2000, water demand for irrigation increased from $13.42 \mathrm{~km}^{3}$ to $15.32 \mathrm{~km}^{3}$ in NX. Similarly it increased from $12.88 \mathrm{~km}^{3}$ to $17.34 \mathrm{~km}^{3}$ in TRB, while in $\mathrm{QH}$, demand decreased from $4.83 \mathrm{~km}^{3}$ to $4.48 \mathrm{~km}^{3}$, mainly due to water-saving practices in the Heihe River Basin. However, in the last 10 years, all the three sub-regions showed an upward trend. The irrigation water demand increased $4.50 \mathrm{~km}^{3}, 3.17 \mathrm{~km}^{3}$ and 0.17 $\mathrm{km}^{3}$ in NX, TRB and $\mathrm{QH}$, respectively.

\subsection{The spatial-temporal features of industrial water demand}

Industrial water use intensity declined from 1985 to 2010. It showed a rapid drop in the first decade (1985-2000) and decreased slowly from 2000 to 2010 in most parts of the study area (Table 2). Due to
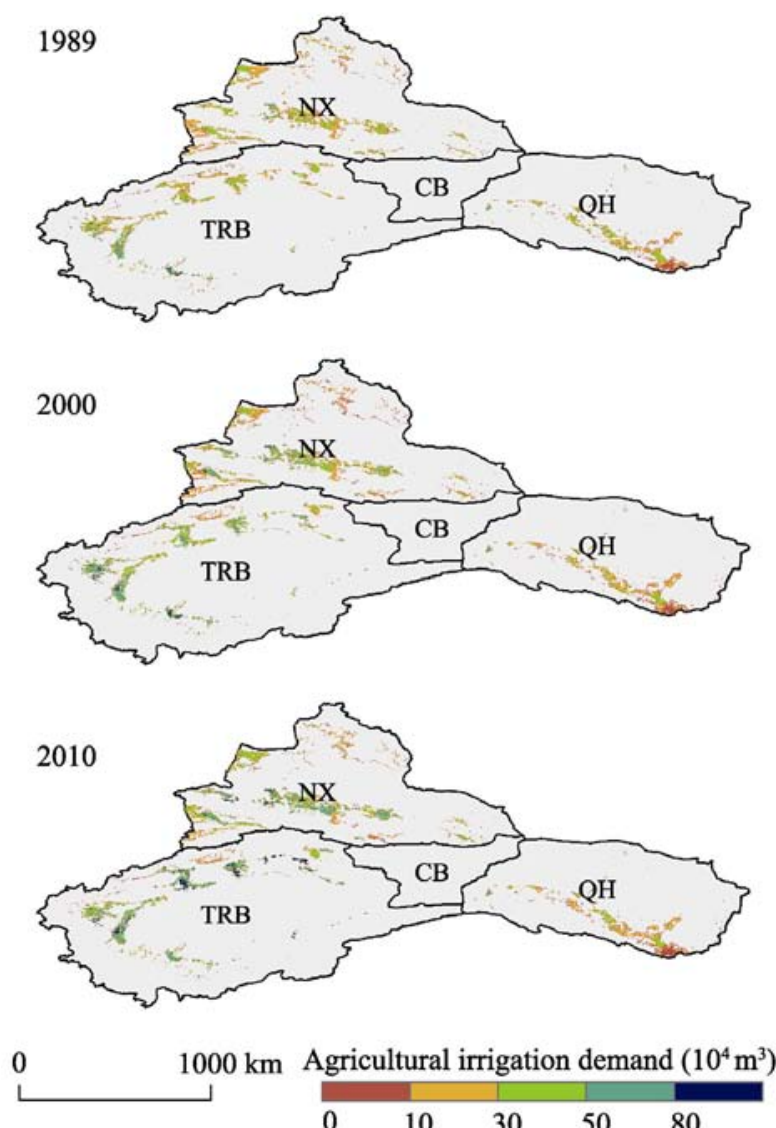

Figure 4 The spatial distribution of agricultural irrigation demand in 1989, 2000 and 2010 in the arid region of northwestern China (spatial resolution $0.01^{\circ} \times 0.01^{\circ}$ )

differences in water use efficiency and water recycling technology, the water use per unit of industrial added value varied in areas, among which the Hotan Prefecture was the highest. Though the largest water use per unit of industrial added value by 2010 was less than 300 $\mathrm{m}^{3} / 10^{4}$ yuan, it can still decline further when compared with the eastern regions of China and other developed countries.

Industrial water demand in the ARNWC has increased rapidly during the past two decades from 1985 to 2010. It was only $0.50 \mathrm{~km}^{3}$ in 1985, but had doubled by $2000\left(0.94 \mathrm{~km}^{3}\right)$ with an increase of $\sim 0.03 \mathrm{~km}^{3} / \mathrm{yr}$. With an accelerating increasing rate $\left(\sim 0.10 \mathrm{~km}^{3} / \mathrm{yr}\right)$, it reached $1.92 \mathrm{~km}^{3}$ by 2010. Secondary industry was mainly scattered in urban areas. The larger the city size and the better the economy, the more industrial water was consumed. The industrial water use in Urumqi took the first place in all the cities which occupied $\sim 15.3 \%$ of the regional total industrial water usage in 2010 (Figure 5). Other cities such as Karamay ( 7.3\%), the Hui Autonomous Prefecture of Changji ( 6.9\%), Counties (Cities) Direct Under Yili Prefecture ( 8.2\%), Bazhou ( 9.9\%), Aksu ( 6.8\%) and Kashgar ( 5.7\%) also had considerable industrial water consumption. In the sub-regions, NX consumed the most industrial water, which was nearly twice that consumed in TRB. The industrial water demand in NX was $0.24,0.50$ and $0.10 \mathrm{~km}^{3}$ in 1985, 2000 and 2010, respectively. For TRB, these 
values were only $0.09,0.25$ and $0.49 \mathrm{~km}^{3}$ in 1985,2000 and 2010, respectively. The industrial water demand in QH was 0.17, 0.19 and $0.39 \mathrm{~km}^{3}$ in 1985, 2000 and 2010, respectively.

Table 2 The water consumption per unit of industrial added value in the main parts of the arid region of northwestern China

\begin{tabular}{|c|c|c|c|c|c|c|}
\hline \multirow[t]{2}{*}{ Region } & \multicolumn{3}{|c|}{$\begin{array}{l}\text { Water use per unit of industrial } \\
\text { added value }\left(\mathrm{m}^{3} / 10^{4} \text { yuan) }\right.\end{array}$} & \multicolumn{3}{|c|}{$\begin{array}{l}\text { Decreasing rate of water use per unit of indus- } \\
\text { trial added value }\left(\mathrm{m}^{3} / \mathrm{yr}\right)\end{array}$} \\
\hline & 1985 & 2000 & 2010 & $\Delta 1985-2000$ & $\Delta 2000-2010$ & $\Delta$ 1985-2010 \\
\hline Karamay & 220.94 & 49.54 & 21.99 & 11.43 & 2.76 & 7.96 \\
\hline Jinchang & 448.33 & 184.03 & 47.10 & 17.62 & 13.69 & 16.05 \\
\hline Jiuquan & 542.15 & 185.88 & 55.19 & 23.75 & 13.07 & 19.48 \\
\hline Urumqi & 558.25 & 108.54 & 49.06 & 29.98 & 5.95 & 20.37 \\
\hline Jiayuguan & 666.04 & 133.99 & 30.57 & 35.47 & 10.34 & 25.42 \\
\hline Hami & 868.13 & 202.45 & 65.93 & 44.38 & 13.65 & 32.09 \\
\hline Tacheng & 881.13 & 206.90 & 78.20 & 44.95 & 12.87 & 32.12 \\
\hline Zhangye & 984.00 & 256.70 & 97.45 & 48.49 & 15.92 & 35.46 \\
\hline $\begin{array}{l}\text { Bortala Mongolian } \\
\text { Autonomous Prefecture }\end{array}$ & 1019.09 & 242.98 & 69.63 & 51.74 & 17.33 & 37.98 \\
\hline Turpan & 1029.85 & 141.89 & 65.15 & 59.20 & 7.67 & 38.59 \\
\hline $\begin{array}{l}\text { Kizilsu Kirghiz } \\
\text { Autonomous Prefecture }\end{array}$ & 1168.84 & 564.66 & 195.72 & 40.28 & 36.89 & 38.93 \\
\hline Changji & 1031.70 & 188.12 & 56.87 & 56.24 & 13.12 & 38.99 \\
\hline $\begin{array}{l}\text { Bayingolin Mongolian } \\
\text { Autonomous Prefecture }\end{array}$ & 1085.85 & 124.85 & 45.86 & 64.07 & 7.90 & 41.60 \\
\hline $\begin{array}{l}\text { Counties (Cities) Direct } \\
\text { under Yili Prefecture }\end{array}$ & 1149.06 & 341.22 & 107.42 & 53.86 & 23.38 & 41.67 \\
\hline Altay & 1147.27 & 246.53 & 81.30 & 60.05 & 16.52 & 42.64 \\
\hline Aksu & 1216.72 & 279.34 & 106.17 & 62.49 & 17.32 & 44.42 \\
\hline Wuwei & 1385.27 & 354.82 & 126.91 & 68.70 & 22.79 & 50.33 \\
\hline Kashgar & 1614.70 & 483.12 & 168.37 & 75.44 & 31.47 & 57.85 \\
\hline Hotan & 1867.88 & 609.72 & 252.54 & 83.88 & 35.72 & 64.61 \\
\hline
\end{tabular}

\subsection{The spatial-temporal features of domestic water demand}

With the increase in population, the development of social economy and the continuous improvement in standard of living, domestic water demand has increased from 0.33 billion $\mathrm{m}^{3}$ in 1985 to $0.79 \mathrm{~km}^{3}$ in 2000, and finally reached $1.29 \mathrm{~km}^{3}$ in 2010. Domestic water use nearly doubled every 10 years in NX, TRB and QH. In 1985, domestic water demand in NX, TRB and QH was just $0.17,0.09$ and $0.07 \mathrm{~km}^{3}$, respectively, and increased to $0.42,0.21$ and $0.16 \mathrm{~km}^{3}$ in 2000. The numbers were $0.66,0.34$ and $0.30 \mathrm{~km}^{3}$ in 2010 . Similar to industrial water demand, domestic water demand was the highest in NX, and the highest site of domestic water use was located in Urumqi (Figure 6).

\subsection{The spatial-temporal features of total water demand}

In this study, the total water demand was obtained by aggregating the agricultural irrigation demand, industrial water demand and domestic water demand. With the increase in each type of water demand, there was a significant upward trend in the total water demand from 

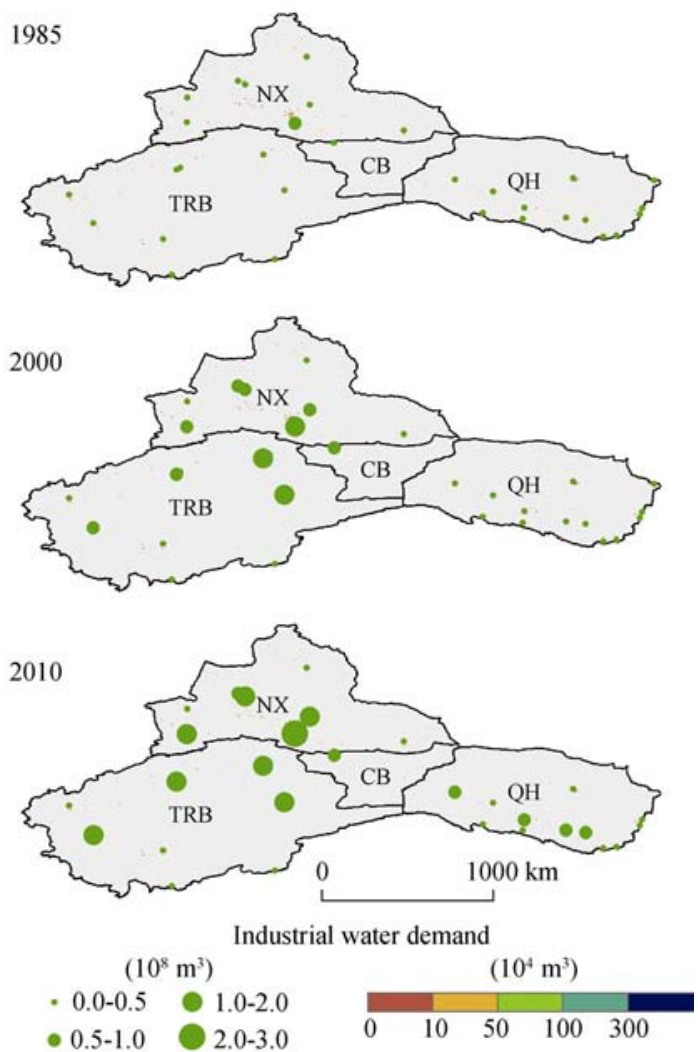

Figure 5 The spatial distribution of industrial water demand and regional water demand in 1985, 2000 and 2010 in the arid region of northwestern China (spatial resolution $0.01^{\circ} \times 0.01^{\circ}$ ) the late 1980s to 2010 in the ARNWC. The total water demand increased from 31.97 $\mathrm{km}^{3}$ in the late 1980 s to $38.88 \mathrm{~km}^{3}$ in 2000 and $48.19 \mathrm{~km}^{3}$ in 2010 . In the sub-regions of the ARNWC, the water demands in NX and TRB were similar, and they composed the majority of the total water demand. From the late 1980 s to 2010 , both the water demand in NX and TRB showed an increase, while there was minor change for the water demand in QH (Figure 7) because of integrated regulation of irrigation water withdrawal and water-saving practices in the river basins.

Agricultural irrigation demand took up more than $90 \%$ of the total water demand, the spatial distribution of the total water demand was similar to the distribution of agricultural irrigation demand. Areas with a large total water demand were mainly distributed in the central part of the northern piedmont of the Tianshan Mountains, followed by the river basins in TRB (Yerqiang, Aksu, and Karshgar), and the basins of Ili River and Ebi Lake in which the demand was more than $3 \mathrm{~km}^{3}$ in 2010 (Figure 8). In total, these regions accounted for $\sim 56 \%$ of the total annual water use in the ARNWC in 2000 and 2010. Unlike the spatial distribution of agricultural irrigation demand, the urban area of Urumqi also had a large total water demand in 2000 and 2010 because of the large amount of industrial and domestic water consumed there.

The spatial change in total water demand in the ARNWC from the late 1980s to 2010 was also analyzed. During the late 1980s to 2010, the water demand in NX increased by 7.68 $\mathrm{km}^{3}$, in TRB by $8.27 \mathrm{~km}^{3}$, but by only $0.26 \mathrm{~km}^{3}$ in $\mathrm{QH}$ because the main farmlands, factories and population are distributed in NX and TRB. As shown in Figure 9, the areas that had a large increase in water demand $\left(>1.5 \mathrm{~km}^{3}\right)$ from the late 1980 s to 2010 were mainly spread over the central part of the northern piedmont of the Tianshan Mountains, followed by the river basins of Aksu, Ebi Lake and Kaikong. The river basins of Yerqiang, Weigan and Ili also had an obvious but smaller increase $\left(1-1.5 \mathrm{~km}^{3}\right.$ ) from the late 1980 s to 2010 . The water demand in these river basins showed a growth trend either from the late 1980s to 2000 or from 2000 to 2010. While the water demand in the Kashgar River Basin had a high increase $\left(\sim 1 \mathrm{~km}^{3}\right)$ from the late 1980s to 2000, the demand decreased $\left(\sim 0.3 \mathrm{~km}^{3}\right)$ from 2000 to 2010 due to the adjustment of plantation structure. The total water demand in the river basins in $\mathrm{QH}$, such as Shiyang, Heihe, and Shule, only saw minor changes. 


\subsection{Analysis of water demand and supply in the ARNWC}

Due to the typical climate in the ARNWC, the distribution of water resources has huge spatial and temporal variation. This may lead to differences between water supply and demand. In this study, the total water demand in the late 1980s, 2000 and 2010 in each river basin were divided by the corresponding average annual river discharge for 1989-2010. This provides a way to measure the water stress on available water resources. A common rule of thumb in water assessment considers that a region is in the condition of severe water limitation when the annual withdrawal exceeds $40 \%$ of the available resources and in medium to high water stress when the annual withdrawal occupies $20 \%$ to $40 \%$ of the available resources. The annual withdrawal refers to the total water demand for agricultural, industrial and domestic purposes (Vörösmarty et al., 2000;
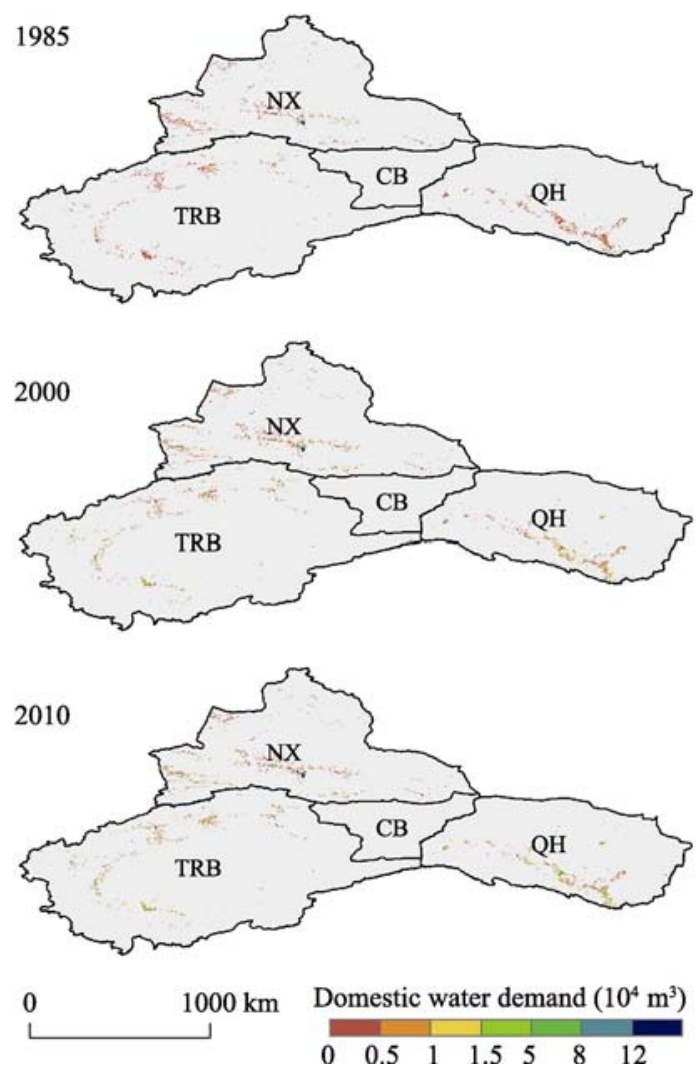

Figure 6 The spatial distribution of domestic water demand in 1985, 2000 and 2010 in the arid region of northwestern China (spatial resolution $0.01^{\circ} \times 0.01^{\circ}$ )

Shen et al., 2013). Figure 10 reflects the spatial distribution of the water stress level for the river basins in the ARNWC. It was highly water stressed in QH because the water demand in the river basins here all exceeded $40 \%$ of the available basin water volume, especially in the Shiyang River Basin. In NX, the high water stress areas were found in the river basins of

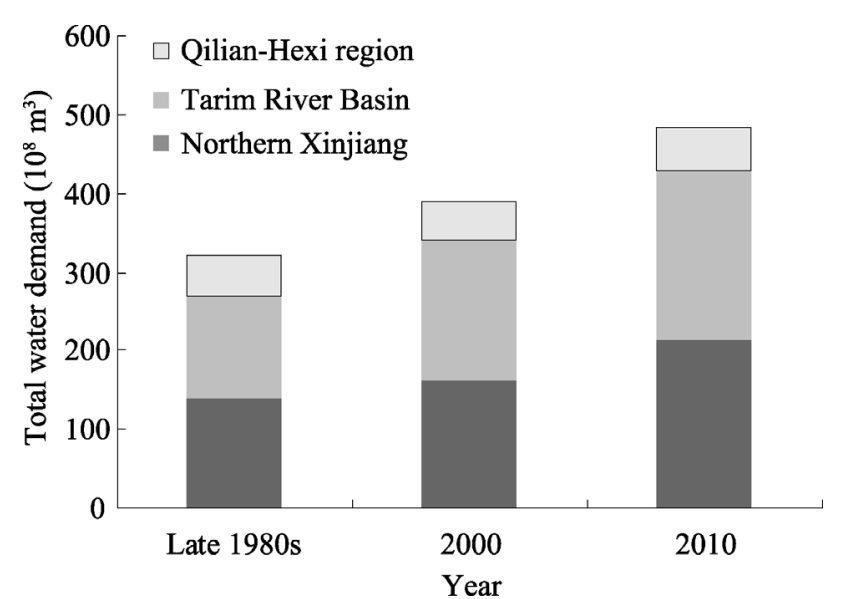

Figure 7 The histogram of total water use in the late 1980s, 2000 and 2010 in the arid region of northwestern China
Jeminay and Emin, and Ebi Lake basin, which are located in its west; the Turpan and Hami basins, which are located in the south; and in the northern piedmont of the Tianshan Mountains, which are located in its center, especially in the eastern portion of the northern piedmont of the Tianshan Mountains. In the TRB, the highly-stressed areas were distributed in the west (Weigan, Kashgar and Yerqiang river basins). During recent years, the water demand in the central part of the 
northern piedmont of the Tianshan Mountains and the Emin River Basin exceeded the available river discharge like the eastern portion of the northern piedmont of the Tianshan Mountains and the Shiyang River Basin. The water stress in the Aksu River Basin also became severe. By 2010, most river basins in the study area faced medium or high water stress except for Irtysh, Keriya, and Qarqan river basins and the Bayi Basin.

As shown in Table 3, the water stress status in the river basins of the ARNWC has developed more serious in the past two decades. Regions such as the northern piedmont of the Tianshan Mountains, the Aksu, Ebi Lake, Weigan, and Kaikong river basins and the Hami Basin had an obvious increase $(>0.3)$ in water stress level. The area with the highest water stress was the eastern part of the northern piedmont of the Tianshan Mountains, followed by the Shiyang River Basin and the central
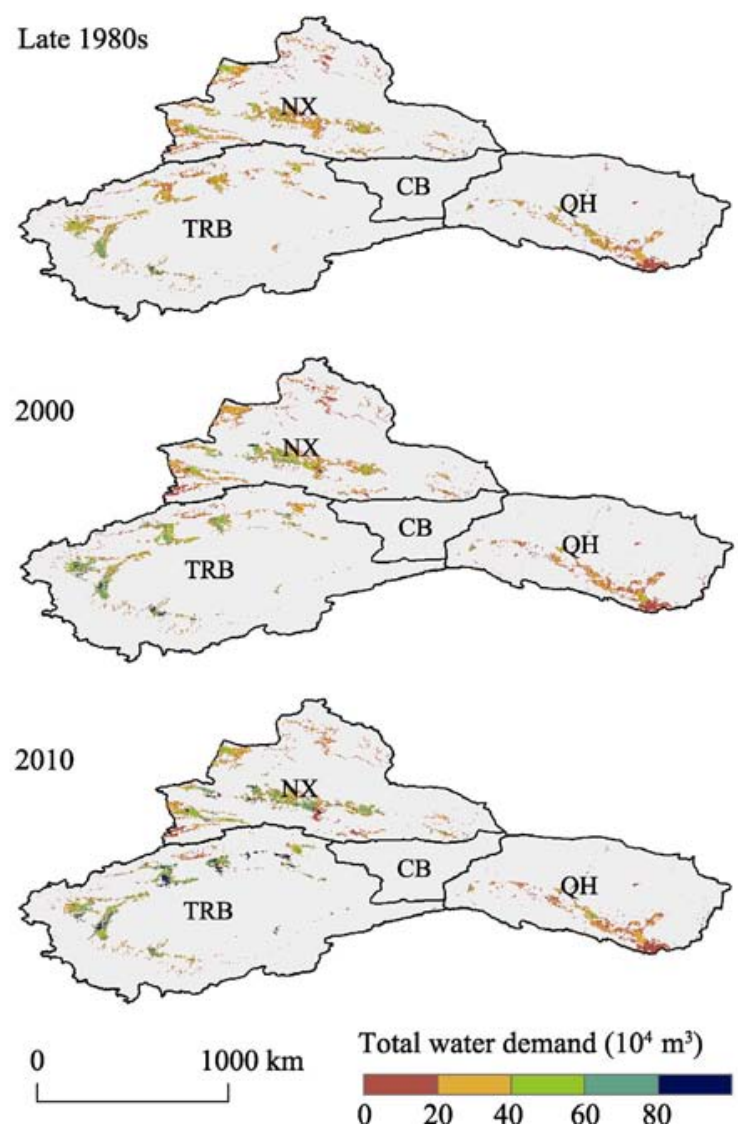

Figure 8 The spatial distribution of total water demand in the late 1980s, 2000 and 2010 in the arid region of northwestern China (spatial resolution $0.01^{\circ} \times 0.01^{\circ}$ ) part of the northern piedmont of the Tianshan Mountains. However, the water stress in the Heihe and Shule river basins was reduced slightly from the late 1980s to 2010 due to the water-saving measures carried out there.

\subsection{Analysis of water demand and supply in some typical basins}

The intra-annual variation of total water demand that consists of agricultural irrigation, industrial and domestic water demand in different river basins was calculated and plotted in Figure 11. We selected five typical river basins to analyze the water supply and demand situation. To obtain a better understanding of the river discharge, we compared the monthly water demand with the river discharges under different assurances of $25 \%, 50 \%$ and $75 \%$ to evaluate the ability of the river basins to supply water resources in key months based on the Pearson-III distribution (Table 4).

By comparing the monthly average river discharges with the total water demand, we found that the water supply and demand varied in river basins. Basically the monthly water demand increased from the late 1980s to 2010. Based on different cropping systems, the monthly water demand was higher during April/May and July/August in TRB, while in QH, it only had one peak, which occurred from May to July. Because the maximum river 
Table 3 The average annual river discharges $\left(10^{8} \mathrm{~m}^{3}\right)$ and water stress level of selected river basins in the late 1980s, 2000 and 2010 in the arid region of northwestern China

\begin{tabular}{|c|c|c|c|c|c|}
\hline & \multirow{2}{*}{ River Basin } & \multirow{2}{*}{$\begin{array}{l}\text { Average annual } \\
\text { river discharge }\end{array}$} & \multicolumn{3}{|c|}{ Water stress level } \\
\hline & & & Late 1980s & 2000 & 2010 \\
\hline \multirow{11}{*}{ NX } & Irtysh & 92.31 & 0.06 & 0.05 & 0.08 \\
\hline & Ili & 161.33 & 0.17 & 0.17 & 0.23 \\
\hline & Wulungu & 8.83 & 0.18 & 0.20 & 0.38 \\
\hline & Bayi Basin & 5.75 & 0.37 & 0.31 & 0.37 \\
\hline & Hami Basin & 4.58 & 0.42 & 0.63 & 1.00 \\
\hline & Ebi Lake & 42.19 & 0.43 & 0.64 & 0.83 \\
\hline & Turpan Basin & 10.56 & 0.48 & 0.49 & 0.47 \\
\hline & Jeminay & 1.18 & 0.76 & 0.49 & 0.70 \\
\hline & $\begin{array}{l}\text { Central part, northern piedmont of } \\
\text { the Tianshan Mountains }\end{array}$ & 53.51 & 0.81 & 1.10 & 1.44 \\
\hline & Emin & 18.69 & 0.98 & 0.83 & 1.12 \\
\hline & $\begin{array}{l}\text { Eastern part, northern piedmont of } \\
\text { the Tianshan Mountains }\end{array}$ & 9.87 & 1.40 & 1.61 & 2.13 \\
\hline \multirow{8}{*}{ TRB } & Qarqan & 21.3 & 0.06 & 0.08 & 0.14 \\
\hline & Keriya & 24.28 & 0.18 & 0.23 & 0.19 \\
\hline & Kaikong & 48.22 & 0.26 & 0.36 & 0.62 \\
\hline & Hotan & 51.37 & 0.29 & 0.35 & 0.30 \\
\hline & Weigan & 36.25 & 0.43 & 0.55 & 0.73 \\
\hline & Yerqiang & 73.73 & 0.44 & 0.54 & 0.62 \\
\hline & Aksu & 45.96 & 0.39 & 0.62 & 0.88 \\
\hline & Kashgar & 47.83 & 0.54 & 0.76 & 0.69 \\
\hline \multirow{3}{*}{$\mathrm{QH}$} & Shule & 13.25 & 0.51 & 0.47 & 0.49 \\
\hline & Heihe & 34.94 & 0.72 & 0.61 & 0.69 \\
\hline & Shiyang & 15.74 & 1.16 & 1.28 & 1.28 \\
\hline
\end{tabular}

discharge usually appears in July and August, there was no water scarcity in the flood season (Figure 11). However, during April-May, temperatures in the mountainous area have not yet increased, and river discharges are low in these river basins, while spring corn and cotton enter the seedling stage and winter wheat enters the jointing and heading stage, which often brings about water shortages.

Different levels of water shortages existed in these river basins. The Yerqiang and Hotan river basins faced higher water stress than the Aksu and Kaikong river basins from March to May (Figure 11). Meanwhile, the water demand in the Heihe River Basin showed a downward trend during March-May from the late 1980s to 2000 due to the water-saving irrigation measures carried out there. However, with the increase in crop area and the changes in cropping pattern, the water demand in the Heihe River Basin increased from 2000 to 2010 during June-August (Figure 11).

The Yerqiang, Aksu and Hotan river basins were similar because the water demand in these river basins exceeded the river discharge with an assurance of $75 \%$ and even of $25 \%$ from March to May (Table 4). In contrast, in the Kaikong River Basin, there was no water 

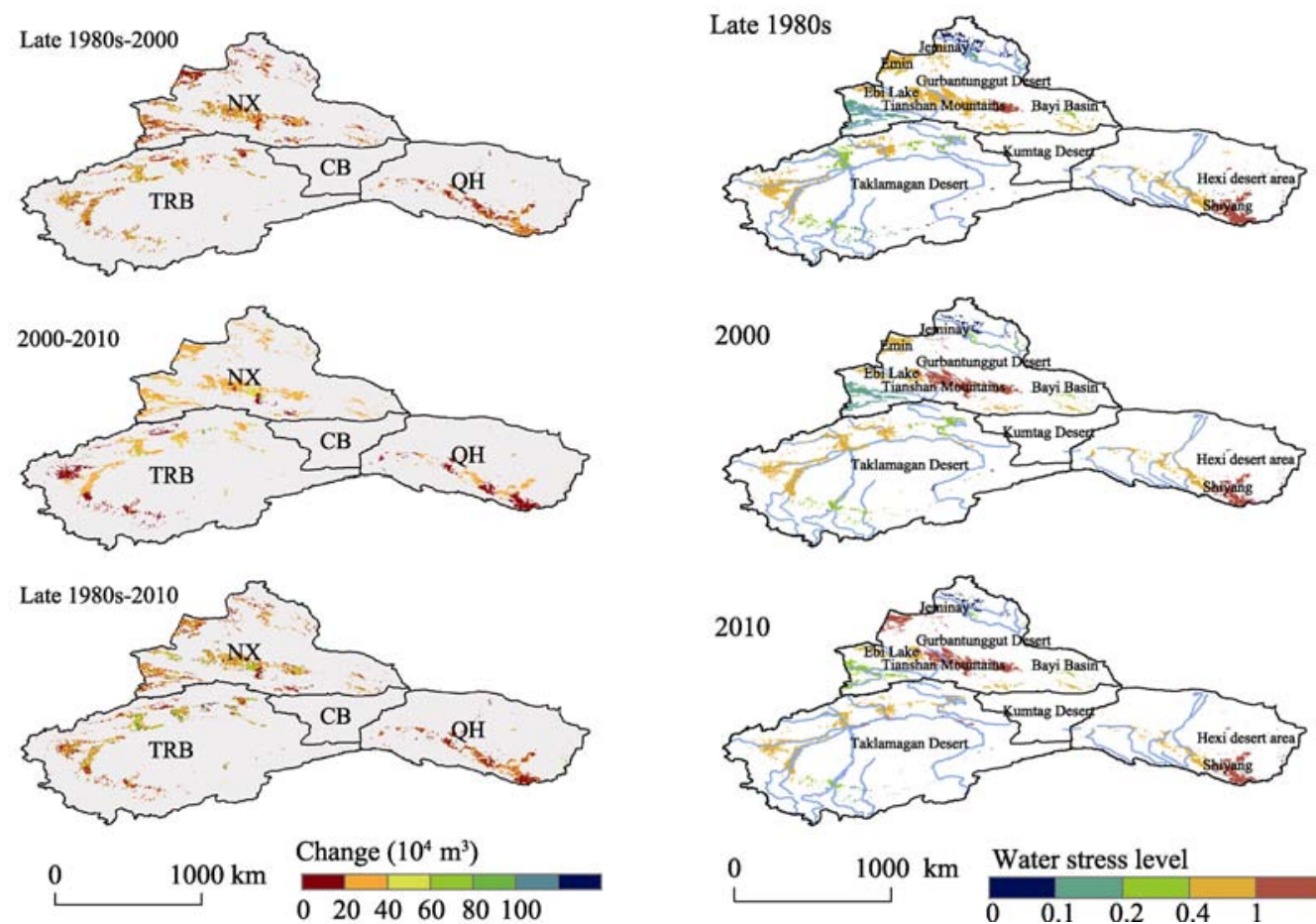

Figure 9 The temporal change of total water demand from the late 1980s to 2000, 2000 to 2010, and the late 1980s to 2010 in the arid region of northwestern China (spatial resolution $0.01^{\circ} \times 0.01^{\circ}$ )

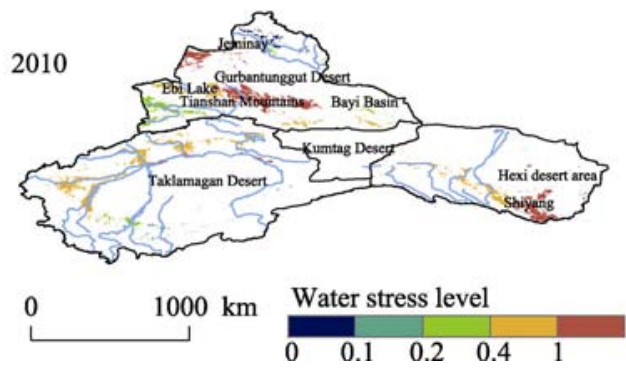

Figure 10 The spatial distribution of water stress levels in the late 1980s, 2000 and 2010 in the arid region of northwestern China

scarcity from the late 1980s to 2010 in March-May because of the plentiful recharge from snowmelt in the Tianshan Mountains. Moreover, the Heihe River Basin faced high water stress during May-June as the water demand there nearly surpassed the river discharge with an assurance of $25 \%$. In general, the river discharges cannot sufficiently meet the water demand every month. With increasing water use, the water shortage situation could become more serious.

\section{Conclusions}

There are few studies in estimating the water resources based on raster data in the ARNWC. In this region, the limited observation data is combined with the remote sensing data to estimate socio-economic water demand through modeling the water demand in agricultural, industrial, and domestic sectors separately. The study results demonstrate that:

(1) Agricultural irrigation demand accounted for more than $90 \%$ of the total water demand in the ARNWC and that the water use for agriculture, industry and domesticity increased significantly from the late 1980s to 2010. By 2010, the total water demand had reached $48.19 \mathrm{~km}^{3}$ in the study area. In the future, with the economic development and growing population, industrial and domestic water use will rise fast. Besides, the change of cropping structure which is affected by the prices and profits of agricultural products also has a strong influence on agricultural irrigation requirement, so the ratios of the three kinds 

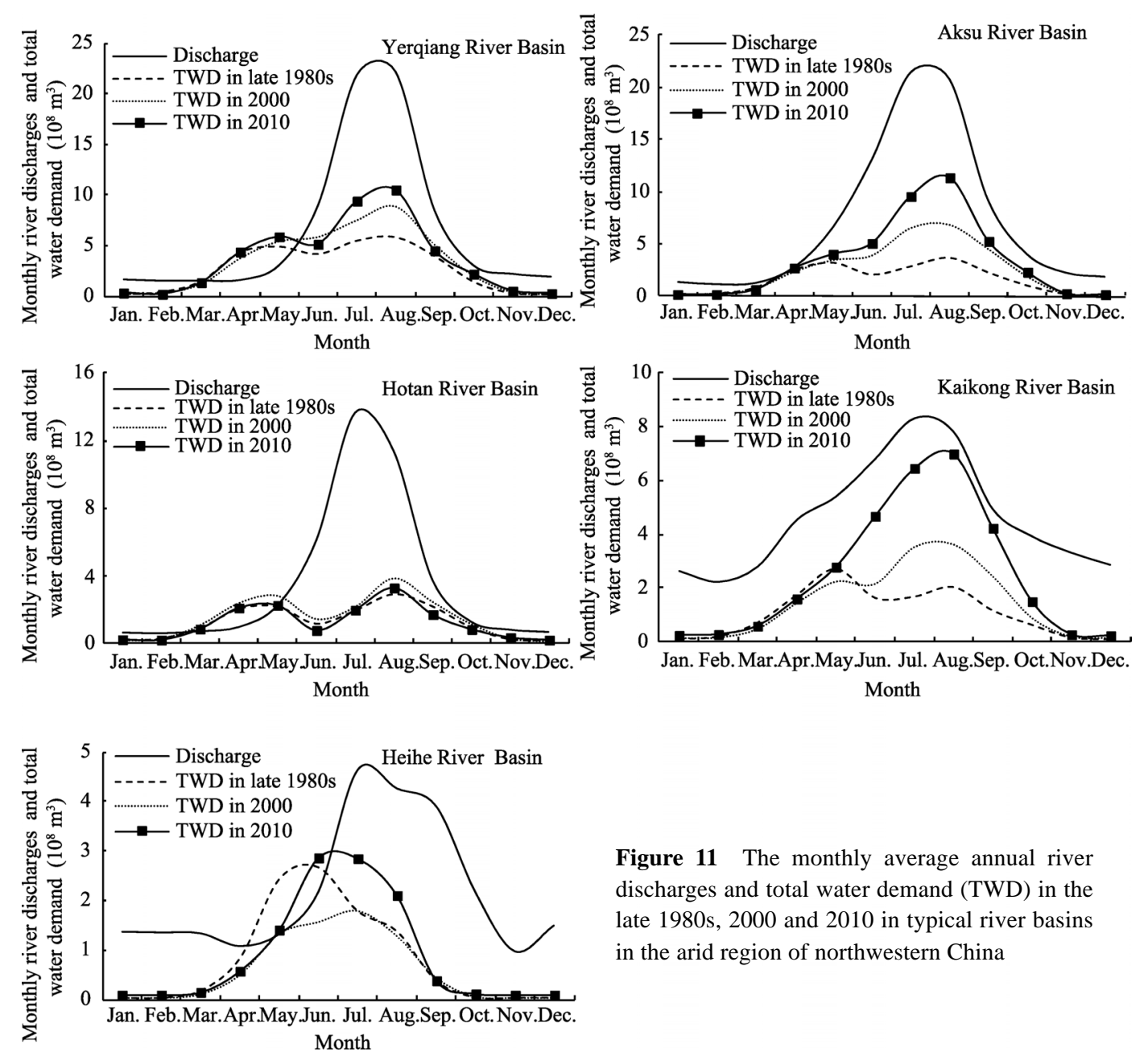

Figure 11 The monthly average annual river discharges and total water demand (TWD) in the late 1980s, 2000 and 2010 in typical river basins in the arid region of northwestern China

of water use may change to some degree.

(2) The water stress in the study area was evaluated based on the total water demand and river discharges. The spatial disparity in the distribution of each type of water demand was apparent. Additionally, high-risk river basins were identified in this arid region, such as the Shiyang River Basin and the eastern part of the northern piedmont of the Tianshan Mountains. Most river basins in this arid region were under medium and high water stress. In some typical river basins, there are great deficits in some critical water-demanding periods, especially in spring. This type of seasonal water shortage strengthened the water stress in the study area. It is urgent that water management measures, such as water price regulation and the implementation of water-saving technologies, to be carried out. To control the cultivated land scale is also a considerable way.

(3) There are some uncertainties in this study in estimating water demand and the pressure on water resources. Due to the lack of data, we distributed the statistical population and GDP in 2010 according to the land-cover data from 2000, and calculated the monthly domestic water demand by dividing the annual values by 12 as an approximation. Thus, the water demand may be overestimated or underestimated. Despite the uncertainties, the modeling results are helpful to assess the water scarcity issue and to provide appropriate sustainable 
Table 4 Total water demand in the late 1980s, 2000, $2010\left(10^{8} \mathrm{~m}^{3}\right)$ and the monthly average annual river discharges under assurances of $25 \%, 50 \%$ and $75 \%$ in key months $\left(10^{8} \mathrm{~m}^{3}\right)$ in the arid region of northwestern China

\begin{tabular}{|c|c|c|c|c|c|c|c|}
\hline \multirow{2}{*}{ River basin } & \multirow{2}{*}{ Month } & \multicolumn{3}{|c|}{ Year } & \multicolumn{3}{|c|}{ Assurance } \\
\hline & & Late 1980 s & 2000 & 2010 & $25 \%$ & $50 \%$ & $75 \%$ \\
\hline \multirow{3}{*}{ Yerqiang } & Mar. & 1.51 & 1.20 & 1.36 & 1.54 & 1.47 & 1.4 \\
\hline & Apr. & 4.35 & 3.75 & 4.38 & 1.71 & 1.44 & 1.25 \\
\hline & May. & 4.88 & 5.42 & 5.89 & 3.63 & 2.88 & 2.25 \\
\hline \multirow{3}{*}{ Aksu } & Mar. & 0.82 & 0.70 & 0.65 & 1.33 & 1.18 & 1.06 \\
\hline & Apr. & 2.56 & 2.36 & 2.72 & 3.22 & 2.26 & 1.75 \\
\hline & May. & 3.24 & 3.47 & 4.05 & 7.77 & 6.2 & 5.01 \\
\hline \multirow{3}{*}{ Hotan } & Mar. & 0.90 & 1.10 & 0.87 & 0.74 & 0.53 & 0.47 \\
\hline & Apr. & 2.06 & 2.39 & 2.12 & 1.09 & 0.84 & 0.7 \\
\hline & May. & 2.20 & 2.82 & 2.27 & 2.6 & 2.11 & 1.75 \\
\hline \multirow{3}{*}{ Kaikong } & Mar. & 0.70 & 0.48 & 0.59 & 3.3 & 2.58 & 2.06 \\
\hline & Apr. & 1.75 & 1.45 & 1.61 & 5.18 & 4.3 & 3.64 \\
\hline & May. & 2.73 & 2.24 & 2.79 & 6.11 & 5.27 & 4.54 \\
\hline \multirow[t]{3}{*}{ Heihe } & May. & 2.43 & 1.34 & 1.41 & 1.51 & 1.12 & 0.92 \\
\hline & Jun. & 2.67 & 1.57 & 2.86 & 2.51 & 1.84 & 1.49 \\
\hline & Jul. & 1.78 & 1.80 & 2.85 & 5.81 & 4.18 & 2.96 \\
\hline
\end{tabular}

water management strategies in the ARNWC. The three water use models not only supply the methodologies to estimate the historical water use but also provide tools for predicting water use in the future.

\section{References}

Alcamo J, DÖLl P, Henrichs T et al., 2003. Development and testing of the WaterGAP 2 global model of water use and availability. Hydrological Sciences Journal, 48(3): 317-337.

Ausubel J H, Victor D G, Wernik I K, 1995. The environment since 1970. Consequences: The Nature and Implications of Environmental Change, 1(3): 2-15.

Bao C, Fang C L, 2007. Water resources constraint force on urbanization in water deficient regions: A case study of the Hexi Corridor, arid area of NW China. Ecological Economics, 62(3/4): 508-517.

Bao C, Fang C L, Chen F, 2006. Mutual optimization of water utilization structure and industrial structure in arid inland river basins of Northwest China. Journal of Geographical Sciences, 16(1): 87-98.

CASGA (Chinese Academy of Sciences Geographic Academy), 1996. Report on sources of arid northwest China. Advance in Earth Sciences, 11(1): 1-3. (in Chinese)

Chen Y N, Ye Z X, Shen Y J, 2011. Desiccation of the Tarim River, Xinjiang, China, and mitigation strategy. Quaternary International, 244: 264-271.

Dai S S, Li L H, Xu H G et al., 2013. A system dynamics approach for water resources policy analysis in arid land: A model for Manas River Basin. Journal of Arid Land, 5(1): 118-131.

Duan A W, Sun J S, Liu Y et al., 2004. Irrigation Quota of Major Crops for Northern China. Beijing: China Agricultual Science \& Technology Press, 197. (in Chinese)

Er-Raki S, Chehbouni A, Guemouria N et al., 2007. Combining FAO-56 model and ground-based remote sensing to estimate water consumptions of wheat crops in a semi-arid region. Agricultural Water Management, 87(1): 41-54.

Feng Q, Cheng G D, Masao M K, 2000. Trends of water resource development and utilization in arid north-west China. Environmental Geology, 39(8): 831-838. 
Feng Z M, Liu D W, 2006. A study on water resources carrying capacity in Jingjinji Region. Journal of Natural Resources, 21(5): 689-699. (in Chinese)

Guo B, 2013. Analysis and prediction of water balance between supply and demand in the Kaidu-Kongqi River Basin [D]. Urumqi: Xinjiang Institute of Ecology and Geography, Chinese Academy of Sciences. (in Chinese)

Guo B, Chen Y N, Shen Y J et al., 2012. Spatially explicit estimation of domestic water use in the arid region of northwestern China: 1985-2009. Hydrological Sciences Journal, 58(1): 162-176.

Ji X B., Kang E S, Chen R S et al., 2006. Analysis of water resources supply and demand and security of water resources development in irrigation regions of the middle reaches of the Heihe River Basin, Northwest China. Agricultural Sciences in China, 5(2): 130-140.

Jia S, Yang H, Zhang S et al., 2006. Industrial water use Kuznets Curve: Evidence from industrialized countries and implications for developing countries. Journal of Water Resources Planning and Management, 132(3): 183-191.

Jon F, Chang H, 2009. Spatial analysis of water use in Oregon, USA, 1985-2005. Water Resources Management, 23(4): 755-774.

Li B F, Chen Y N, Shi X et al., 2013. Temperature and precipitation changes in different environments in the arid region of northwest China. Theoretical and Applied Climatology, 112(3/4): 589-596.

Li W H, Chen Z S, Li B F et al., 2012. Analysis of water demand and stability for oasis in Kaidu-Kongque River Basin, southern Xinjiang. Journal of Glaciology and Geocryology, 34(6): 1470-1477. (in Chinese)

Liu J G, Diamond J, 2005. China’s environment in a globalizing world. Nature, 435(7046): 1179-1186.

Nian Y Y, Li X, Zhou J et al., 2014. Impact of land use change on water resource allocation in the middle reaches of the Heihe River Basin in northwestern China. Journal of Arid Land, 6(3): 273-286.

Oki T, Kanae S, 2006. Global hydrological cycles and world water resources. Science, 313(5790): 1068-1072.

Piao S L, Ciais P, Huang Y et al., 2010. The impacts of climate change on water resources and agriculture in China. Nature, 467(7311): 43-51.

Qi H G, Chen Y N, Li H M et al., 2010. Analysis of water resources based on SD model in Yanqi County. Quaternary Sciences, 30(1): 209-215. (in Chinese)

RMN (Rural Migration News). 2012. Global: Population, climate [online]. Rural Migration News, 18(3). Available from: http://migration.ucdavis.edu/rmn/more.php?id=1709_0_5_0.

Shen Y J, Chen Y N, 2010. Global perspective on hydrology, water balance, and water resources management in arid basins. Hydrological Process, 24: 129-135.

Shen Y J, Chen Y N, Liu C M et al., 2013. Ecohydrology of the inland river basins in the Northwestern Arid Region of China. Ecohydrology, 6: 905-908.

Shen Y J, Li S, Chen Y N et al., 2013. Estimation of regional irrigation water requirement and water supply risk in the arid region of northwestern China 1989-2010. Agricultural Water Management, 128: 55-64.

Shen Y J, Liu C M, Liu M et al., 2010. Change in pan evaporation over the past 50 years in the arid region of China. Hydrological Processes, 24(2): 225-231.

Shen Y J, Oki T, Kanae S et al., 2014. Projection of future world water resources under SRES scenarios: An integrated assessment. Hydrological Sciences Journal, 59: 1775-1793.

Shen Y J, Oki T, Utsumi N et al., 2008. Projection of future world water resources under SRES scenarios: Water withdrawal. Hydrological Sciences Journal, 53(1): 11-33.

Tang Q C, Zhang J B, Cheng W M, 2002. Prediction to water supply-demand balance for West China. Journal of Natural Resources, 17(3): 327-332. (in Chinese)

Vassolo S, Döll P, 2005. Global-scale gridded estimates of thermoelectric power and manufacturing water use. Water Resources Research, 41, W04010, doi: 10.1029/2004WR003360.

Vörösmarty C J, Green P, Salisbury J et al., 2000. Global water resources: vulnerability from climate change and population growth. Science, 289: 284-288.

Wang H J, Chen Y N, Xun S et al., 2013. Changes in daily climate extremes in the arid area of northwestern China. Theoretical and Applied Climatology, 112(1/2): 15-28.

WB (World Bank), 2013. World Development Indicators: Freshwater. Washington DC, USA: World Bank.

Xia J, Chen Y D, 2001. Water problems and opportunities in the hydrological sciences in China. Hydrological Sciences Journal, 46(6): 907-921.

Xu X B, Zhou H P, Wang Z et al., 2010. Study on effective rainfall use efficiency in arid irrigation district. Water Saving Irrigation, 12: 44-46, 50. (in Chinese) 